\title{
Stability of Deep Underground Mine Drift through Complex Geology Conditions in Quang Ninh Coal Area
}

\author{
Dang VAN KIEN ${ }^{1, \star)}, V^{0}$ TRONG HUNG $^{1)}$ Do NGOC ANH ${ }^{1),}$ Do NGOC THAI ${ }^{1),}$ \\ Dao VAN CHI ${ }^{1)}$
}

\footnotetext{
1) Hanoi University of Mining and Geology, Hanoi, Vietnam; email: dangvankien@humg.edu.vn; vongochung@humg.edu.vn; dongocanh@humg.edu.vn; dongocthai@humg.edu.vn; daovanchi@humg.edu.vn
}

http://doi.org/10.29227/IM-2020-02-27

Submission date: 06-03-2020 | Review date: 22-09-2020

\begin{abstract}
The stability of deep underground mine drifts is pivotal to sustainable, safe mining in underground coal mines. The main objective of this research is to determine the stability and drifting safety issues in 500-m-deep deep underground mine drift through complex geology in the Quang Ninh coal area. The laboratory experimentation and field measurements were used to analyze the large deformations and failure characteristics of the surrounding rock, the influence factors of safe excavation and stability of deep underground mine drift, and to study the stability control countermeasures. This study also shows the main factors influencing the stability and drifting safety include complex geology zones, high in situ stress, poor mechanical properties and engineering performance of the argillaceous rock mass. According to the field study, the groutability of cement-matrix materials in the argillaceous rock in the complex geology zones were extremely poor, and deformations and failure of the surrounding rock were characterized by dramatic initial deformation, high long-term creep rate, obviously asymmetric deformations and failure, the rebound of roof displacements, overall loosened deformations of deep surrounding rock on a large scale, and high sensitivity to engineering disturbance and water immersion. Various geo-hazards occurred during the underground mine drift excavation, including roof collapse, groundwater inrush. Control techniques are proposed and should be adopted to ensure drifting safety and to control the stability of deep underground mine drift through complex geology zones, including choice of reasonable drift shape, reasonable support type, steel sets, regional strata reinforcement technique such as ground surface pre-grouting, primary enhanced control measures, grouting reinforcement technique, and secondary enclosed support measures for long-term stability, which are critical for ensuring the sustainable development of the underground coal mine.
\end{abstract}

Keywords: deep underground drift; argillaceous rock; complex geology; underground coal mine; drift excavation; drift deformation; grouting; stability

\section{Introduction}

Deeper underground mining exploitation is increasing in Viet Nam because near surface mineral resources become gradually depleted. In-situ stress increasing in rock is the main difference between rock stresses at depth compared to the rock near the surface, and dynamic activities are direct consequences of such a condition. Understanding the possible ground behaviour type is an essential part in stability analysis and good rock support design in deep underground drift excavations, especially in difficult and complex ground conditions. The main ground behaviour types in deep underground drift excavations can be classified as follow considering the rock mass type, the stress condition, the presence of water, the condition of major geological structures, time.

Extreme ground behaviour in high stress rock masses such as squeezing ground conditions is encountered in a range of underground projects mining applications. The occurrence of such ground behaviour types are difficult to predict, and special design and construction measures and support requirements must be considered to control them as follow:

There are no universal standard analyses for determining ground support requirements in deep underground mine drift, because each design is specific to the circumstances at the actual site, the ground conditions, the project related features and the regulations and experience. The deep under- ground mine drift surrounding rock mass and the excavation forms an extremely complex structure. It is seldom possible, neither to acquire the accurate mechanical data of the ground and forces acting nor to theoretically determine the exact interaction of these, which makes support design for a drift a challenging task [1-3]. Prediction and/or evaluation of support requirements for drifts are largely based on observations, experience and engineering judgment of those involved in drift construction. Often, the estimates are backed by theoretical approaches in support design mainly include the classification systems, the ground-support interaction analysis and the key block analysis.

The stability of underground mine drift is mainly governed by three factors: the quality of the rock mass, the in situ rock stresses and the size and geometry of the excavation. The essential difference between rock at depth and rock near the surface is an increase in the in situ rock stresses. The high stresses can lead to two consequences in underground mine drift: large deformations in soft and weak rock masses and sudden failure in hard and massive rock masses. The rock mass response is mainly stress-driven, and conventional support measures do not adapt well to these difficult conditions at high depths [4]. The main task of rock support in shallow underground excavations is to prevent rock blocks from falling by the installation of conventional rock bolts which must 


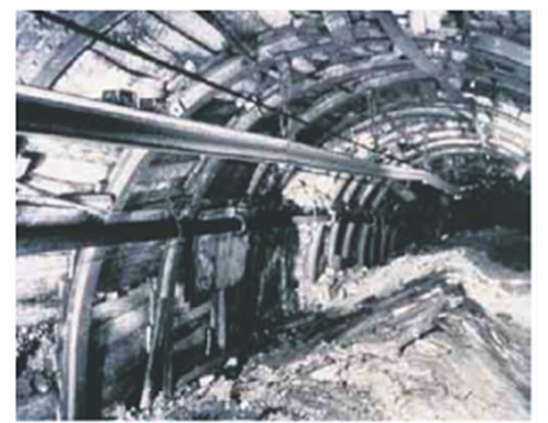

Fig. 1. The collapses of deep underground drift floor at Quang Ninh coal mine area [1]

Rys. 1. Zawalenie się głębokiej podziemnej sztolni w zagłębiu węglowym Quang Ninh [1]
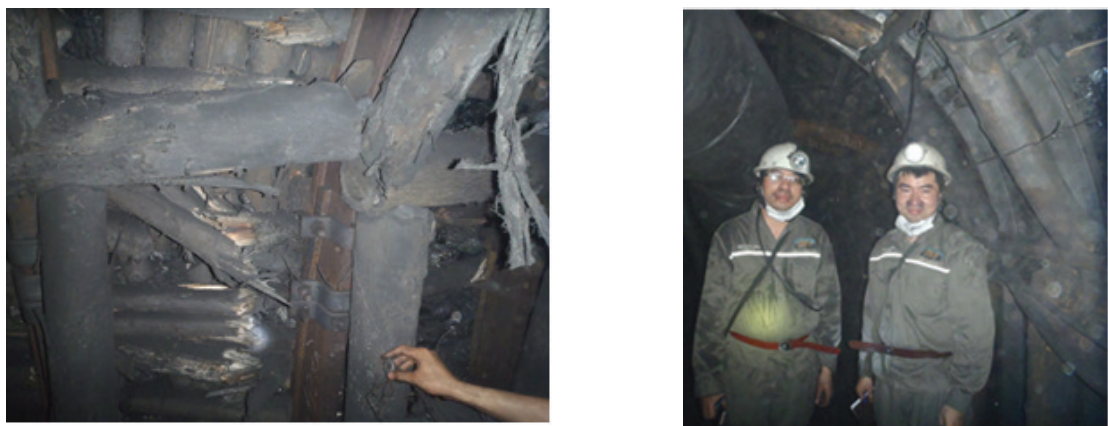

Fig. 2. Some typical failures in deep drifts in Mao Khe coal mine (by authors)

Rys. 2. Niektóre typowe awarie w głębokich sztolniach w kopalni Mao Khe (zdjęcia autorów)

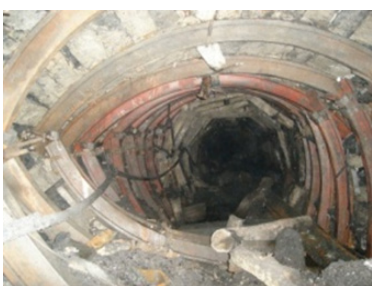

Fig. 3.The collapses of drift floor of deep underground drift at Dong Ri coal mine [1] Rys. 3. Zawalenie się spągu sztolni głębokiej kopalni Dong Ri [1]

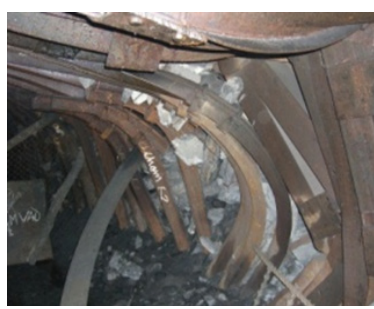

Fig. 4. The failure on right sidewall of deep underground drift at Dong Ri coal mine [1] Rys. 4. Awaria na prawej bocznej ścianie sztolni głębokiej podziemnej kopalni Dong Ri [1]

be strong enough to bear the deadweight of the loosened rock block. This is called a load-controlled condition [5]. Therefore, in low in situ stress conditions, the strength of the rock bolt is more important than its deformation capacity. The task of rock support at great depths and high in situ stress conditions is to prevent the failed rock from disintegration, and the support system must be not only strong but also deformable (energy absorbent) in order to deal with either stress-induced rock squeezing in weak and fractured rocks or rockburst in hard and massive rocks.

This paper addresses the main characteristics and support requirements of squeezing ground conditions and investigates the relative performance of different ground support options. Different types of energy-absorbing rock bolts, surface supports and yielding elements applicable for ground support in high stress grounds, are introduced. Ground support benchmarking data and mitigation measures for mines squeezing ground conditions are briefly presented by some examples in practice.

The term "squeezing rock" originates from the pioneering days of drifting in the Alps. Terzaghi [7] provides one of the earliest and scientific descriptions of squeezing rock behaviour with respect to drifting as follow: "Squeezing rock slowly advances into the drift without perceptible volume increase. Prerequisite of the squeeze is a high percentage of mi- 

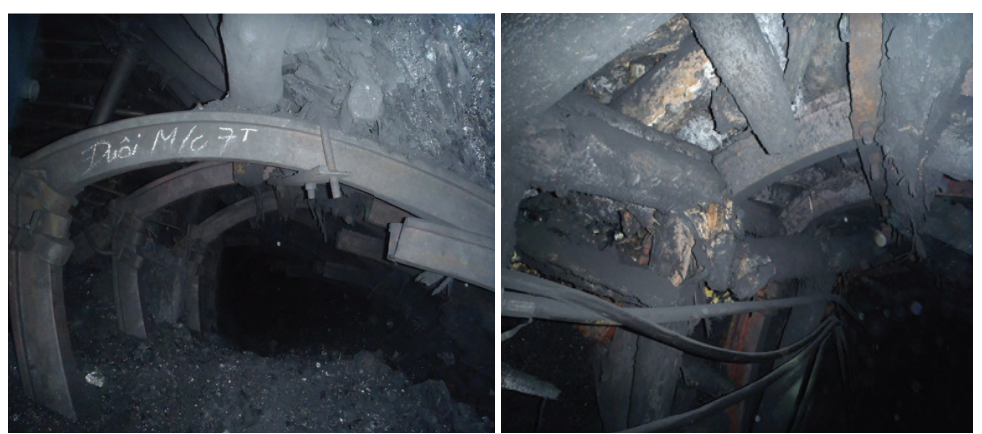

Fig. 5. The collapses of drift at seam 10 level -25 in Mao Khe coal mine, Quang Ninh province [2] Rys. 5. Zawalenie się sztolni na pokładzie 10 na poziomie -25 w kopalni węgla Mao Khe, prowincja Quang Ninh [2]

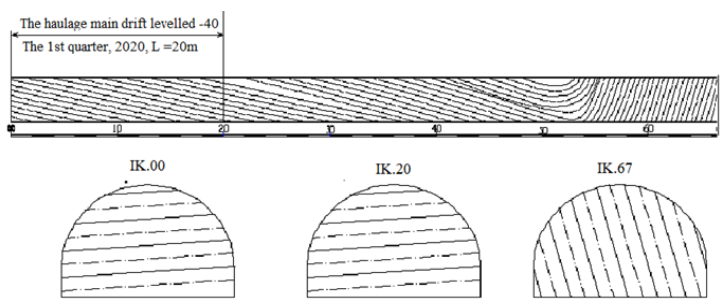

Fig. 6. Section of geological profiles of the drift levelled -40 in the Nam Mau coal company [6] Rys. 6. Przekrój profili geologicznych sztolni na poziomie -40 w Spółce węglowej Nam Mau [6]
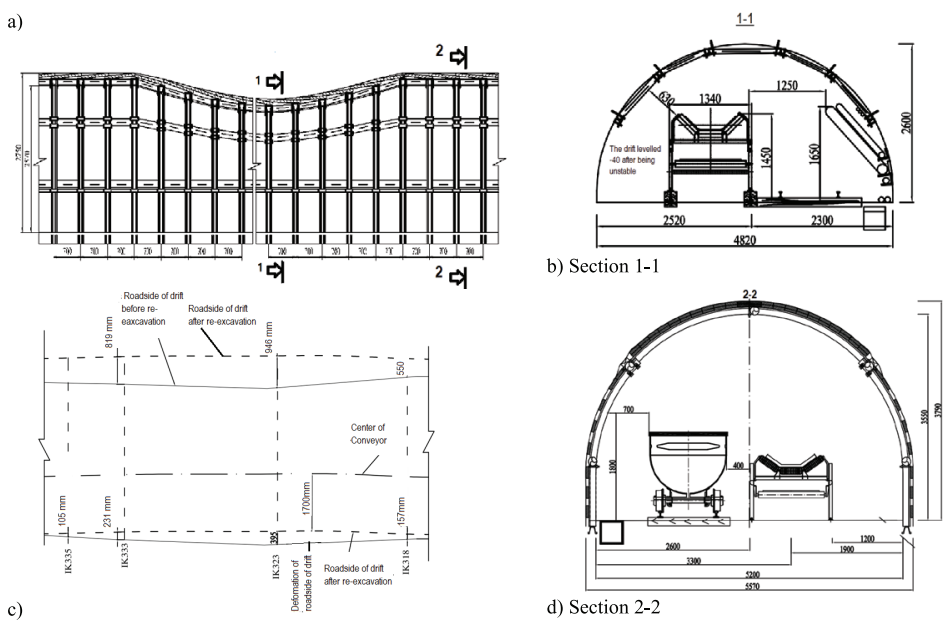

c)

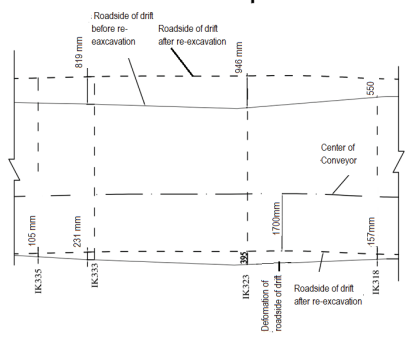

Fig. 7. Failure of the drift levelled -40 in the Nam Mau coal company through complex geology conditions [38] Rys.7. Awaria wyrobiska na poziomie -40 z powodu złożonych warunków geologicznych w Spółce węglowej Nam Mau

croscopic and sub-microscopic particles of micaceous minerals or of clay minerals with a low swelling capacity." Some authors [8-37] provided a general description of squeezing in rocks from the phenomenological point of view by distinguishing between three failure mechanisms as:

- Complete shear failure: generally observed in continuous ductile rock masses or in masses with widely spaced discontinuities;

- Buckling failure: This type of failure being generally observed in metamorphic rocks and thinly bedded ductile sedimentary rocks;

- Shearing and sliding failure: Generally observed in relatively thickly bedded sedimentary rocks.

Large deformations refer to squeezing pose a considerable challenge in the construction and maintenance of un- derground excavations in rock. Squeezing conditions imply a reduction in the cross-sectional area of excavation. Squeezing conditions are encountered in both civil drifts and in mining drives in poor quality or weak rock but also in structurally defined rock masses. Weak rock masses behave in a different manner from stronger rock masses when subjected to tangential stresses, and show significant time-dependent deformation behaviour under high stress conditions. In weak rock masses such as shale and phyllite, when the strength is less than the induced

Rebars and Split Sets are low energy-absorbing devices and are used mainly to deal with instability problems under low or relatively low rock stress conditions. The desired type of rock bolt for rock support in high stress rock masses should not only have a high load-bearing capacity but also should be able to accommodate large deformations. In other words, 


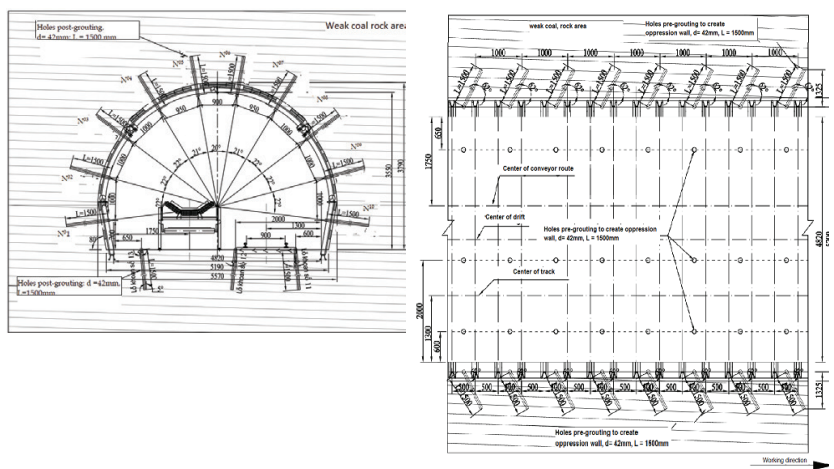

Fig. 8. Pipe layout diagram of $1.5 \mathrm{~m}$-deep holes post-grouting during re-excavation at drift levelled -40 in Nam Mau coal company, Uong Bi, Quang Ninh, Viet Nam [38]

Rys. 8. Schemat rozmieszczenia rur otworów o głębokości 1,5 m po spoinowaniu podczas ponownego wykopu przy wypoziomowaniu sztolni -40 w Spółce węglowej Nam Mau, Uong Bi, Quang Ninh, Wietnam [38]
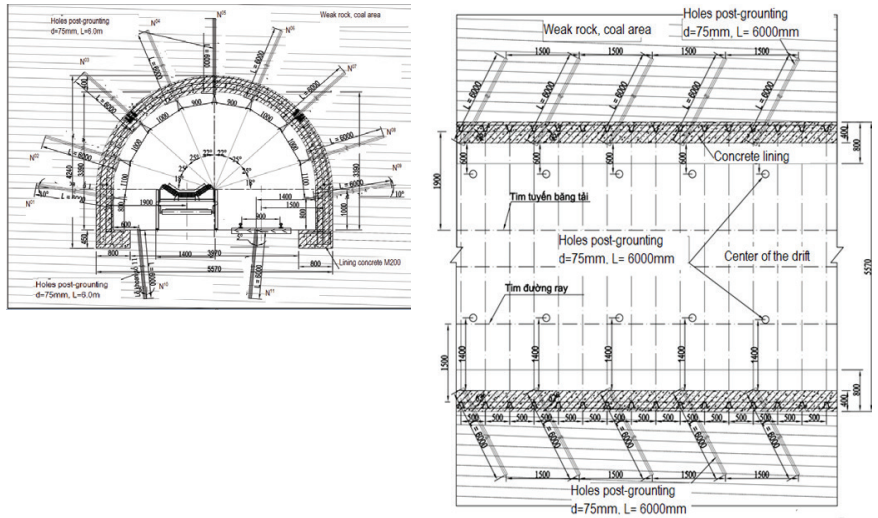

Fig. 9. Pipe layout diagram of $6.0 \mathrm{~m}$-deep holes post-grouting during re-excavation at drift levelled -40 in Nam Mau coal company, Uong Bi, Quang Ninh, Viet Nam [38]

Rys. 9. Schemat rozmieszczenia rur otworów o głębokości 6,0 m wykonanych po spoinowaniu podczas ponownego wykopu na poziomie -40 w Spółce Węglowej Nam Mau, Uong Bi, Quang Ninh [38]

they should be able to absorb a large amount of energy prior to failure. When absorbing the same amount of energy, the bolt exhibiting the least displacement is preferred since it is more efficient in restraining rock movement. Energy-absorbing rock bolts are suitable for supporting not only the burstprone ground but also squeezing the rock.

\section{Factors influencing safe excavation and the stability of} deep underground drift in Quang Ninh coal area

High in situ stress of deep underground drift in Quang Ninh coal area:

The in-situ stress in the underground drift was calculated by $\mathrm{K}$. Terzaghi theory [2] in two long horizontal and vertical direction in the $400 \mathrm{~m}$-deep in Nam Mau coal mine, where the rock mass was weak. According to the results of the calculation, the magnitudes of the vertical stress and the maximum and minimum principal horizontal stresses were $28.78 \mathrm{MPa}$ $(\sigma \mathrm{H}), 16.34 \mathrm{MPa}(\sigma \mathrm{h})$, and 18.08 $\mathrm{MPa}(\sigma \mathrm{v})$, respectively. The horizontal-to-vertical stress coefficient $(\lambda=\sigma \mathrm{H} / \sigma \mathrm{v}=1.6)$ was more than 1.0. The underground drift is in an extremely highstress area. The orientation of the maximum horizontal stress is nearly in the EW direction. The directions of the maximum and minimum principal horizontal stresses are approximately perpendicular to and parallel to the south underground drift axis, respectively.
The higher the in-situ stress, the larger the deviator stress after excavation. The radial stress orr decreases to 0 at the surface of the drift, whereas the tangential stress $\sigma \theta \theta$ increases after excavation, resulting in a contradiction between the high stress and low rock mass strength and will inevitably lead to the rapid degradation of the surrounding rock mass after excavation. This is an important factor for deformations, failure, and instability of the deep underground drift through the complex geology.

Low rock mass strength of deep underground drift in Quang Ninh coal area:

At the deep underground drift in Quang Ninh coal area, the rock mass was extremely broken in geological. The strength of the surrounding rock is extremely low. The roof collapses can be easily attributed to the broken soft rock mass after excavation about one month [1-3]. According to the classification of surrounding rock in rock drifts for coal mines, the classification of the surrounding rock of the through the complex geology is very weak. The compressive strength of rock mass was generally less than 1.6 MPa [1-3]. Destruction types of drift in deep mines in some underground mines in Quang Ninh are shown in Fig. 1 to Fig.5.the study area (Fig. 2b).

Cause of the instability of mine drift due to the rock mass around the mine drift is crumpled, heavily compressed. 
Fig. 7. Failure of the drift levelled - 40 in the Nam Mau coal company through complex geology conditions [38] Rys.7. Awaria wyrobiska na poziomie -40 z powodu złożonych warunków geologicznych w Spółce węglowej Nam Mau

\begin{tabular}{|c|c|c|c|}
\hline Parameters & Symbol & Value & Unit \\
\hline Unit weight & $\gamma$ & 0,26 & $\mathrm{MN} / \mathrm{m} 3$ \\
\hline Tensile Strength & $\sigma \mathrm{k}$ & 0,5 & $\mathrm{MPa}$ \\
\hline Cohesion & $\mathrm{c}$ & 0,025 & $\mathrm{MPa}$ \\
\hline Friction angle & $\varphi$ & 35 & Deg. \\
\hline Young's modulus & $\mathrm{E}$ & 1000 & $\mathrm{MPa}$ \\
\hline Poisson's ratio & $\mu$ & 0,30 & - \\
\hline Dilation angle & $\psi$ & 0 & Deg. \\
\hline Friction angle (resid) & $\varphi r e$ & 28 & Deg. \\
\hline Cohesion (resid) & cre & 0,02 & $\mathrm{MPa}$ \\
\hline Material type & - & Elastic-Plastic & - \\
\hline Failure criterion & Mohr-Coulomb & - & - \\
\hline
\end{tabular}

\section{A case study at Nam Mau coal mine}

Introduction to the Nam Mau Coal Mine:

The Nam Mau Coal Mine is in Uong Bi City, Quang Ninh Province, $150 \mathrm{~km}$ from Hanoi capital, Viet Nam. It is one of the big coal mines owned by TKV, that provides an important energy source for the rapid, sustainable economic growth of Viet Nam, producing an annual coal output of more than 30 million tons (Mt) since 2009 , reaching a maximum of $3.0 \mathrm{Mt} /$ year.

Geological profiles of deep underground mine drift :

The haulage and rail underground drift levelled -40 , with a horizontal width of $5.0 \div 6.0 \mathrm{~m}$ in the first mining level of $40 \mathrm{~m}$, playing a pivotal role in the sustainable development of the Nam Mau coal mine with high output. The geological profiles of deep underground mine drift structures exist that are extremely complex, as shown in Figure 6.

According to [6], the area of drift No. 1 levelled - 40 is located near Nam Mau branch stream. Nam Mau stream is the integration of stream system from Yen Tu mountain range that flows and flows into the Trung Luong river. Water depth varies with seasons from $0.3 \mathrm{~m} \div 1.0 \mathrm{~m}$. The average flow is $2 \div 128.8 \mathrm{l} / \mathrm{s}$ in the dry season, but the speed of water is very fast in the rainy season. Currently, the drift No. 1 levelled - 40 is higher than the height of the Nam Mau stream. The drift No. 1 levelled - 40 is through the fine-grained rock mass. The average thickness of stratified rock seam is $(0.4 \div 0.6) \mathrm{m}$ with the rock consolidating coefficient by M.N. Protodyakonov: $\mathrm{f}=6 \div 8$, and $\mathrm{f}=8 \div 10$, some sections was through coal seams with the consolidating coefficient of rock by M.N. Protodyakonov: $\mathrm{f}=2 \div 3$.

Deformations, failure characteristics, and factors influencing deep underground drift through complex geology:

After a period of using, the drift No. 1 levelled - 40 has become unstable. Especially, the quarry drifts near the above mining area are very unstable. The instability is often compressed to reduce the height of the drift (see Fig.7.a,b), collapses of drift floor, collapses of sidewalls (see Fig.7.c), They make the dimension of drift is reduced so much. The instability manifestations are shown in Figure 7.

\section{Some solutions to improve the stability of the under- ground mine drift}

To improve the stability of the underground mine drift, some solutions can be carried out, which depend on the actual condition of mine. Nowadays, by equipment and material development and increasing our knowledge and understand- ing of ground behaviour, more complex and difficult ground conditions can be managed and more advanced support systems can be used to control the ground behaviour in underground excavations under high in-situ stress conditions. The high stresses can lead to two consequences in underground excavations: rock squeezing in soft and weak rock masses and brittle rock masses. Some solutions can be used to improve the stability of the underground mine drift such as choice of reasonable drift shape, reasonable support type, steel sets, regional strata reinforcement technique such as ground surface pre-grouting, primary enhanced control measures, grouting reinforcement technique, and secondary enclosed support measures for long-term stability, which are critical for ensuring the sustainable development of the coal mine. In this paper, the field study at Nam Mau coal mine through complex geology conditions are presented.

Floor grouting reinforcement technique with pressurization and progressive depths:

The floor heave of the underground drift is critical. The floor must be reinforced given the destructive floor heave. However, the holes drilled in the floor are always subjected to collapse because of the soft broken coal seams with the rock consolidating coefficient by M.N. Protodyakonov: $f=2 \div 3$. The bolts and cables cannot be installed on the floor. Based on the industrial testing of the floor reinforcement during the working of drift, we proposed the floor grouting reinforcement technique with pressurization and progressive depths. Grouting depths in the floor successively increased from shallow to deep, and the corresponding grouting pressure also progressively increased ( see Figure 8). The array pitch and the water-to-cement ratio for $1.5 \mathrm{~m}$-deep holes grouting were $1: 1$. The earlier shallow holes grouting not only reinforces the shallow rock mass but also forms a stop-grouting layer for subsequent deeper drilling holes grouting and solves the problem of a wall collapse in deeper holes. The six m-deep holes with grouting with superfine cement reinforce the deep rock mass in the floor and forms a large joint bearing ring with the reinforced deep rock mass in the roof and sidewalls. The displacement velocity of the floor decreased, providing a foundation for secondary enclosed support measures for the long-term stability of the surrounding rock.

Shallow holes post-grouting with superfine cement:

Shallow holes pre-grouting with superfine cement was completed (Figure 8). The lengths of the grouting pipes and boreholes were $1500 \mathrm{~mm}$, and the array pitch was $1000 \mathrm{~mm}$. 


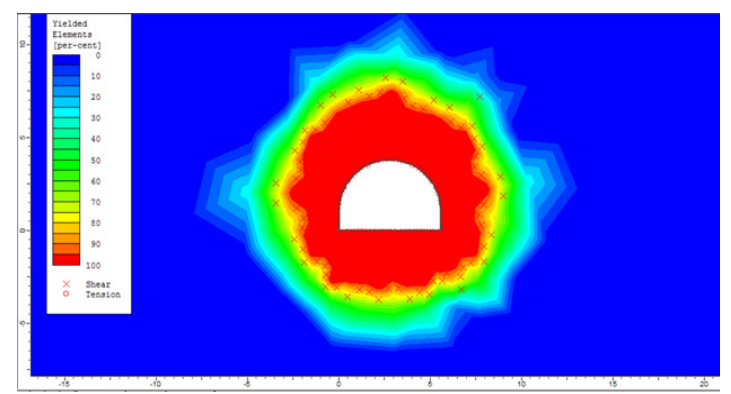

Fig. 10. Damaged zones around the drift before post-grounting Rys. 10. Uszkodzone strefy wokół wyrobiska przed fugowaniem

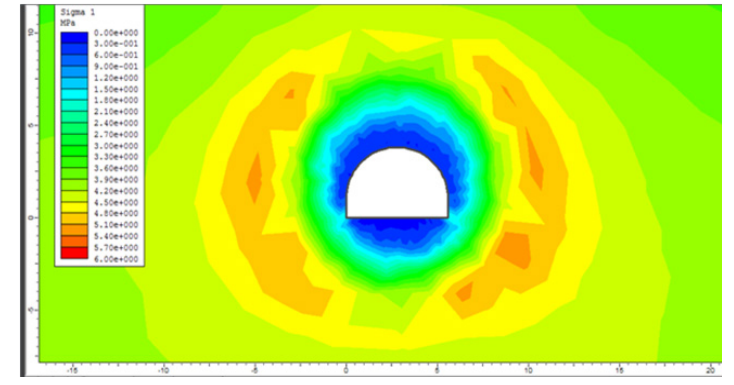

Fig. 11. Stress around the drift before post-grounting Rys. 11. Naprężenie wokół wyrobiska przed fugowaniem

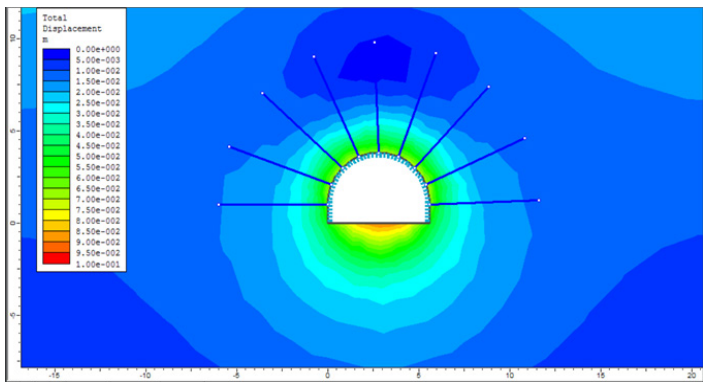

Fig. 12. Displacement around the drift after post-grouting Rys. 12. Przemieszczenie wokół wyrobiska po fugowaniu

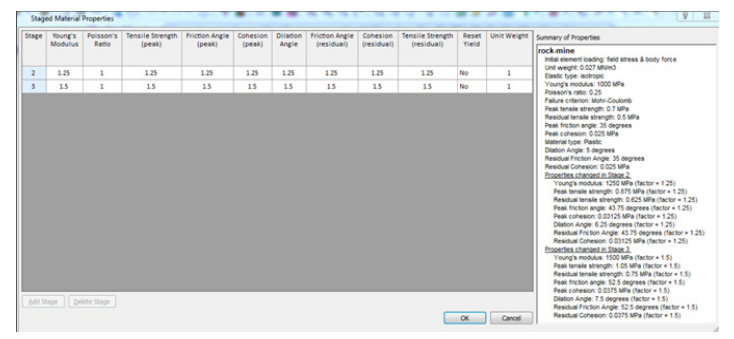

Fig. 13. Staged material properties of rock mass after post-grouting Rys. 13. Etapowe właściwości materiałów górotworu po fugowaniu

Grouting pressure was generally not more than $3.0 \mathrm{MPa}$. The strength of the superfine cement was $62.5 \mathrm{MPa}$. The water-to-cement ratio was $0.8-1.0$. The distance of shallow holes pre-grouting relative to the drifting face was less than $6.0 \mathrm{~m}$.

Deep holes post-grouting with superfine cement:

Deep holes post-grouting with superfine cement were bored after secondary shotcrete (see Figure 9). The lengths of grouting pipes and boreholes were $6000 \mathrm{~mm}$. The array pitch average was $1000 \mathrm{~mm}$. The grouting pressure was $6.0 \div 8.0 \mathrm{MPa}$.
To improve the grouting effect, deep post-grouting was conducted by a repeated grouting method with alternating intervals; i.e., the odd array holes grouting was first completed along the opening axis direction. Afterwards, the grouting of the remaining even array holes was conducted. In addition, the deep holes post-grouting sequences at the same cross-section were from holes No.1 and No.9 on the sidewalls; then holes No. 2 and No. 8 in the shoulders, to the last hole No.3 to No.7 in the arch crown; No.10 and No.11in the floors (see Figure 9). 


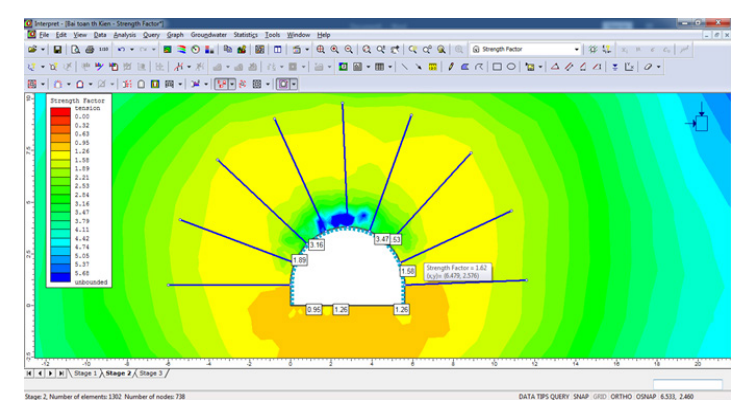

Fig. 14. Strength factor of rock mass in stage 2

Rys. 14. Współczynnik wytrzymałości górotworu w etapie 2

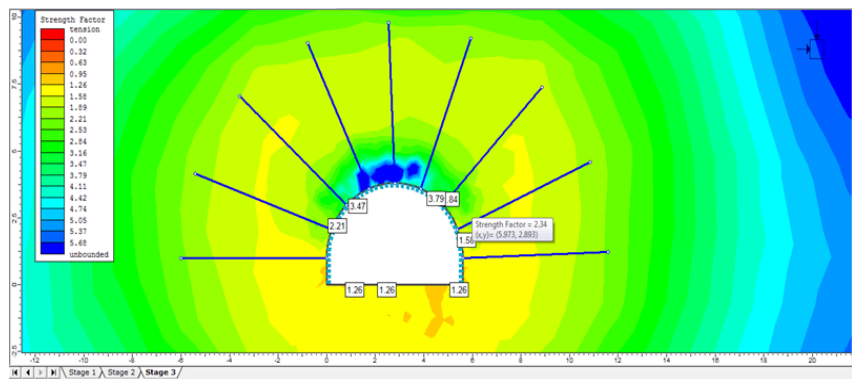

Fig. 15. Strength factor of rock mass in stage 3

Rys. 15. Współczynnik wytrzymałości górotworu w etapie 3

\section{Numerical modelling of the post-grouting to improve the stability of the underground mine drift}

Numerical simulations were performed using the Finite Element Method with the Phase 2.0 software. The 2D model was used in this research. Using $2 \mathrm{D}$ models permits to validate the mesh and investigate some parameters of the model. The rock mass was modelled using the elastic perfectly plastic constitutive model (with a Mohr-Coulomb failure criterion). The parameters of the rock mass see in Table 1 . Result of numerical simulations of before post-grouting and after post-grouting are presented from Fig. 10 to Fig. 15. The model is studied on three stages: stage 1- before post-grouting; stage 2- The grouting work has just been completed; stage 3 - The grouting work has been completed in time. Parameters of rock mass after being reinforced by grouting using as input ones are friction angle (resid) and cohesion (resid), also Young's modulus (E). The cohesion (resid), Young's modulus (E) is increased by the post-grouting process, the rock mass surrounding the drift can be able to carry of self-loading after grouting.

The criteria to determine whether a drift has sufficient capacity to sustain the external load effects is the strength factor of the rock mass. The strength factor is calculated by dividing the rock strength (based on failure criteria, the model used the Mohr-Coulomb failure criterion) by the induced stress at every point in the mesh. All three principal stresses have an influence on the strength factor (Sigma 1, Sigma 3 and Sigma Z).

By the numerical model, the efficiency of grouting solution has been investigated. The result of the numerical model on Fig.10 to Fig. 12 shows the stress and displacement induced in the rock mass surrounding the drift. The friction angle (resid) and cohesion (resid), also Young's modulus (E) is increased by the post-grouting process as the Fig.13. It also shows that Young's modulus (E) is increased 1.25 times higher than before grouting by shallow holes post-grouting with superfine cement (Stage 2) and increased 1.5 times higher than before grouting by deep holes post-grouting with superfine cement (Stage 3). The strength factor of rock mass after grouting is presented in Fig.14 and Fig.15. Strength factor of rock mass at the roof, shoulder of drift in stage 2 is more than 1.0, but the strength factor of rock mass on some points at the left floor is less than 1.0 (Fig.14). Strength factor of rock mass of stage 3 in which the grouting work has been completed in time is higher than stage 2. All of them are higher than 1.0. It shows that the capacity to sustain the external load effects of rock mass after grouting is guaranteed (see Fig.15).

\section{Conclusions and Proposals}

The stability of deep underground mine drift during operation determines the sustainable safety production in underground coal mines. This work was a case study on the stability control of $500 \mathrm{~m}$-deep underground mine drift in Nam Mau coal mine, Uong Bi, Quang Ninh. The results were based on the analysis of long-term engineering practices and a numerical model that provide valuable practical guidance for the stability control of deep underground mine drift in other coal mines with similar geological conditions, such as the Mao Khe, Dong Ri coal mine. Some conclusions and research prospects are summarized below:

- Deformation and Failure Characteristics: Engineering practices in-situ indicated that deformations and failure of the surrounding rock of deep underground mine drift, obviously asymmetric deformations and failure, the rebound of roof displacements, overall loosened deformations of deep surrounding rock mass on a large scale and high sensitivity to engineering disturbance and water immersion.

- Minimum range of pre-grouting and post-grouting reinforcement for deep underground drift through complex 
geology. According to engineering practices and numerical model, the minimum pre-reinforcement range around the proposed deep underground opening through complex rock mass should be $15 \mathrm{~m}$. Moreover, the minimum reinforcement range of deep holes post-grouting should be completed to improve the strength and intactness of the 6-8 m-deep surrounding rock mass.

- Influencing Factors: The main factors influencing safe excavation and the stability of deep underground mine drifts include high in situ stress, poor mechanical properties and engineering performance of the argillaceous surrounding rock mass, groundwater inrush.

- Pre-Grouting and deep holes post-grouting: The experimental results at Nam Mau coal mine shows that the pre-grouting and deep holes post-grouting with superfine cement should be used to block fracture water from seeping, and prevent the deep complex rock mass. The numerical model indicated that deep holes post-grouting with superfine cement were able to improve the intactness of deep rock mass but also improves the bearing load-ability of the rock mass.

- Suggestions of coordinated control techniques

According to the deformations and failure characteris- tics of the surrounding rock, the factors influencing the safe excavation and the stability and geo-hazards encountered, coordinated control techniques, including regional strata reinforcement technique such as Pre-grouting and deep holes post-grouting, primary enhanced control measures of the surrounding rock, floor grouting reinforcement technique with pressurization and progressive depths, and secondary enclosed support are proposed and should be adopted to ensure the drift safety and long-term stability of deep underground openings through complex geology.

- The strength factor of rock mass

The criteria to determine whether a drift has sufficient capacity to sustain the external load effects is the strength factor of the rock mass. The result of the numerical model show that strength factor of rock mass at the roof, shoulder of drift in stage 2 in which the grouting work has just been completed is more than 1.0, but the strength factor of rock mass on some points of the left floor is less than 1.0. Strength factor of rock mass of stage 3 in which the grouting work has been completed in time is higher than stage 2. All of them are higher than 1.0. It shows that the capacity to sustain the external load effects of rock mass after grouting is guaranteed. 


\section{Literature - References}

1. Institute of Science and Technology- Vinacomin - 2015, Final Report Topic: Research, develop standards and inspection procedures for rock support in undergound mining in Quang Ninh area.

2. Tran Tuan Minh.Research on choosing reasonable and flexible steel-resistant structures for basic stone kilns in thick seams and steep slopes, applied to Uong Bi-Quang Ninh coal area . Ministry-level project B2018.MDA.

3. Do Quang Dai, Le Tien Anh - Student class K59 of Underground and Mining Construction Department. Study on solution of reinforcing furnace line in weak rocky soil containing high pressure water in the mine mine, the company of thorns coal company - Vinacomin. The 32nd sudent scientific research topic, Hanoi University of Mining and Geology (HUMG), Ha Noi-2019.

4. Report of project: Proposing a plan to deal with unstable furnace conditions, fast deformation, large basement due to complex geotechnical conditions in main wells, sub-wells of $+15 \div-160$, the kiln road along seam $-50,-160$ seam 11 at the project of Cai Da quarry - Suoi Lai mineral - Hon Gai coal company - TKV.

5. E. Hoek, P.K. Kaiser, W.F. Bawden, Support of underground excavation in hard rock. Rotterdam, Balkema, 1995.

6. K. Terzaghi, Rock defects and loads on drift supports. Introduction to drift geology, in: Rock drifting with steel

7. Supports, (eds. R. V. Proctor and T. L. White), 1946, pp. 5- 153.

8. Yang, W.; Lin, B.Q.; Qu, Y.A.; Li, Z.W.; Zhai, C.; Jia, L.L.; Zhao, W.Q. Stress evolution with time and space during mining of a coal seam. Int. J. Rock Mech. Min. Sci. 2011, 48, 1145-1152.

9. Wang, L.; Cheng, Y. Drainage and utilization of Chinese coal mine methane with a coal-methane Co-exploitation Model: Analysis and Projections. Resour. Policy 2012, 37, 315-321.

10. State Administration of Work Safety of China. Available online: www.Chinasafety.gov.cn (accessed on 15 October 2015).

11. Liu, Q.S.; Zhang, W.; Lu, X.L.; Fu, J.J. Safety monitoring and stability analysis of large-scale roadway in fault fracture zone. Chin. J. Rock Mech. Eng. 2010, 29, 1954-1962.

12. Liao, Q.L.; Hou, Z.S.; He, X.D.; Dong, W.L.; Xiao, Q.B. Monitoring and analysis on the deformation of tunnel surrounding rock affected by fault. Hydrogeol. Eng. Geol. 2005, 32, 102-107.

13. Hao, Y.H.; Azzam, R. The plastic zones and displacements around underground openings in rock masses containing a fault. Tunn. Undergr. Space Technol. 2005, 20, 49-61.

14. Schubert, W.; Riedmüller, G. Influence of faults on tunnelling. Felsbau 1997, 15, 483-488.

15. Jeon, S.; Kim, J.; Seo, Y.; Hong, C. Effect of a fault and weak plane on the stability of a tunnel in rock-A scaled model test and numerical analysis. Int. J. Rock Mech. Min. Sci. 2004, 41, 658-663.

16. Russo, M.; Germani, G.; Amberg, W. Design and construction of large tunnel through active faults: A recent application. In Proceedings of the International Conference of Tunnelling and Underground Space Use, Istanbul, Turkey, 16-18 October 2002.

17. Lei, J.; Bai, M.Z.; Xu, Z.Y.; Zhang, A.J.; Huo, Y.H.; Wang, P.C. In-situ test on construction effect with freezing method for fault-crossing fragmentation zone in metro tunnel. Chin. J. Rock Mech. Eng. 2008, 27, 1492-1498.

18. Zhang, N.; Xu, X.L.; Chen, Z.F.; Wang, C. Geological guarantee and construction controlling technique of main roadway crossing fault zone with 435-m fall. Chin. J. Rock Mech. Eng. 2008, 27, 3292-3297.

19. Gao, Y.; Liu, D.; Zhang, X.; He, M. Analysis and Optimization of Entry Stability in Underground Longwall Mining. Sustainability 2017, 9, 2079.

20. Zhang, Z.; Shimada, H.; Sasaoka, T.; Hamanaka, A. Stability control of retained goaf-side gateroad under different roof conditions in deep underground y type longwall mining. Sustainability 2017, 9, 1671.

21. Qian, D.; Zhang, N.; Shimada, H.; Wang, C.; Sasaoka, T.; Zhang, N. Stability of goaf-side entry driving in 800-m-deep island longwall coal face in underground coal mine. Arab. J. Geosci. 2016, 9, 1-28.

22. Qian, D.; Zhang, N.; Zhang, M.; Shimada, H.; Cao, P.; Chen, Y.; Wen, K.; Yang, S.; Zhang, N. Application and evaluation of ground surface pre-grouting reinforcement for $800-\mathrm{m}$-deep underground opening through large fault zones. Arab. J. Geosci. 2017, 10, 1-20.

23. Wang, C.; Wang, Y.; Lu, S. Deformation behaviour of roadways in soft rocks in underground coal mines and principles for stability control. Int. J. Rock Mech. Min. Sci. 2010, 37, 937-946.

24. Fabre, G.; Pellet, F. Creep and time-dependent damage in argillaceous rocks. Int. J. Rock Mech. Min. Sci. 2006, 43, 950-960.

25. Blümling, P.; Bernier, F.; Lebon, P.; Martin, C.D. The excavation damaged zone in clay formations time-dependent behaviour and influence on performance assessment. Phys. Chem. Earth 2007, 32, 588-599. 
26. Liu, Q.S.; Kang, Y.S.; Bai, Y.Q. Research on supporting method for deep rock roadway with broken and soft surrounding rock in Guqiao Coal Mine. Rock Soil Mech. 2011, 32, 3097-3104.

27. Yuan, L.; Xue, J.H.; Liu, Q.S.; Liu, B. Surrounding rock stability control theory and support technique in deep rock roadway for coal mine. J. China Coal Soc. 2011, 36, 535-543.

28. Liu, Q.S.; Gao, W.; Yuan, L. Surrounding Rock Stability Control Theory and Support Technique in Deep Rock Roadway for Coal Mine and Application; Science Press: Beijing, China, 2010; pp. 77-82, 257-258. ISBN 978-7-03026333-9. (In Chinese)

29. Qian, D. Countermeasures for Stability Control of Deep Underground Openings through Fault Zones in Argillaceous Rock. Ph.D. Dissertation, Kyushu University, Fukuoka, Japan, 2015.

30. Mánica, M.; Gens, A.; Vaunat, J.; Ruiz, D.F. A time-dependent anisotropic model for argillaceous rocks. Application to an underground excavation in Callovo-Oxfordian claystone. Comput. Geotech. 2017, 85, 341-350.

31. Wang, L.L.; Bornert, M.; Yang, D.S.; Héripré, E.; Chanchole, S.; Halphen, B.; Pouya, A.; Caldemaison, D. Microstructural insight into the nonlinear swelling of argillaceous rocks. Eng. Geol. 2015, 193, 435-444.

32. Wang, L.L.; Yang, R.W.; Chanchole, S.; Zhang, G.Q. The time-dependent swelling of argillaceous rock under resaturated conditions. Appl. Clay Sci. 2017, 146, 186-194.

33. Guan, X.M.; Zhong, Q.F. Research on the Performance of Micro-fine Cement-based Grouting Material and Its Engineering Application. Saf. Coal Mines 2013, 44, 142-145.

34. Zhao, Y.; Li, G.; Xu, X.; Yu, X. Transient process control technology for argillaceous roadway with water seepage. Disaster Adv. 2013, 6, 44-54.

35. Li, G.; Jiang, Z.; Lv, C.; Chao, H.; Gui, C.; Li, M. Instability mechanism and control technology of soft rock roadway affected by mining and high confined water. Int. J. Min. Sci. Technol. 2015, 25, 573-580.

36. Vergara, M.R.; Triantafyllidis, T. Influence of water content on the mechanical properties of an argillaceous swelling rock. Rock Mech. Rock Eng. 2016, 49, 1-14.

37. Yang, R.S.; Li, Y.L.; Guo, D.M.; Yao, L.; Yang, T.M.; Li, T.T. Failure mechanism and control technology of water-immersed roadway in high-stress and soft rock in a deep mine. Int. J. Min. Sci. Technol. 2017, 27, 245-252.

38. Guo, H.; Yuan, L.; Shen, B.T.; Qu, Q.D.; Xue, J.H. Mining-induced strata stress changes, fractures and gas flow dynamics in multi-seam longwall mining. Int. J. Rock Mech. Min. Sci. 2012, 54, 129-139.

39. Ngo Doan Hao, Dang Van Kien, Do Ngoc Thai. Report of project: Research and application of grouting method to improve the stability of the drifts in Nam Than Coal Company - Ha Noi. 2020.

\section{Stabilność wyrobisk $w$ głębokiej kopalni podziemnej drążonych $w$ złożonych warunkach geolo- gicznych w zagłębiu węgla kamiennego Quang Ninh}

Stabilność sztolni $w$ głębokiej podziemnej kopalni ma kluczowe znaczenie dla zrównoważonego i bezpiecznego wydobycia w podziemnych kopalniach wegla. Głównym celem tych badań jest określenie zagadnień ze stabilnością i bezpieczeństwem wyrobisk w głębokiej na 500 m podziemnej kopalni drążonej przez złożoną geologię w zagłębiu węgla Quang Ninh. Doświadczenia laboratoryjne i pomiary terenowe posłużyly do analizy dużych odkształceń i charakterystyk zniszczenia otaczającej skały, czynników wplywających na bezpieczne wydobycie i stabilność sztolni oraz do zbadania środków zaradczych kontroli stabilności. Badanie to pokazuje również, że główne czynniki wpływające na stabilność i bezpieczeństwo wyrobisk obejmuja złożone strefy geologiczne, wysokie naprężenia, słabe właściwości mechaniczne i parametry inżynieryjne górotworu ilastego. Zgodnie z badaniami terenowymi, fugowalność materiałów osnowy cementowej $w$ skale ilastej $w$ złożonych strefach geologicznych była wyjątkowo słaba, a odkształcenia i uszkodzenia otaczającej skały były nastęstwem dramatycznego odkształcenia poczatkowego, wysokiej długoterminowej szybkości pełzania, oczywiście asymetrycznej. odkształcenia i uszkodzenia, odbicia przemieszczeń stropu, ogólne poluzowane odkształcenia głęboko otaczającej skały na duża skalę oraz duża wrażliwość na zakłócenia inżynieryjne i zanurzenie w wodzie. Podczas wykonywania sztolni w kopalniach podziemnych wystepowały różne zagrożenia geologiczne, w tym zawalenie się stropu, naplyw wód gruntowych. Proponowane sa techniki kontrolne, które należy przyjąć, aby zapewnić bezpieczeństwo procesu drążenia i kontrolować stabilność wyrobisk przechodzących przez złożone strefy geologiczne, w tym wybór rozsądnego kształtu wyrobiska, rozsądnego typu podpory, zestawów stalowych, regionalnych technik wzmacniania warstw, takich jak wstępna powierzchnia gruntu, podstawowe wzmocnione środki kontroli, technika zbrojenia spoinowania i dodatkowe zamknięte środki wspierające dla długoterminowej stabilności, które sa kluczowe dla zapewnienia zrównoważonego rozwoju podziemnej kopalni wegla.

Słowa kluczowe: głębokie podziemne sztolnie; skały ilaste; złożona geologia; podziemna kopalnia węgla; wykopy sztolniowe; deformacja dryfu; fugowanie; stabilność 